KONSTAN
JURNAL FISIKA DAN PENDIDIKAN FISIKA
Volume 3, Nomor 2, Juni 2018
E-ISSN : 2460-9129 dan P-ISSN : 2460-9110
http://jurnalkonstan.ac.id/index.php/jurnal

\title{
ANALISIS PERGESERAN LEMPENG BUMI YANG MENINGKATKAN POTENSI TERJADINYA GEMPA BUMI DI PULAU LOMBOK
}

\author{
Yanita Syafitri $^{1}$, Bahtiar ${ }^{1}$, Lalu A. Didik ${ }^{1}$ \\ ${ }^{1}$ Program Studi Tadris Fisika Fakultas Tarbiyah dan Keguruan Universitas Islam Negeri \\ Mataram, NTB, Indonesia
}

\section{Info Artikel \\ Sejarah Artikel: \\ Diterima November 2019 \\ Disetujui Desember 2019 \\ Dipublikasikan Desember 2019}

\section{Kata Kunci:}

Pergeseran, lempeng

bumi, Gempa bumi

\begin{abstract}
Abstrak
Penelitian ini merupakan sebuah penelitian kualitatif. Dimana tujuan dari penelitian ini adalah untuk mengetahui bagaimana pergeseran-pergeseran lempeng bumi yang ada di sekitar Pulau Lombok mampu meningkatkan frekuensi dari potensi terjadinya gempa bumi di Pulau Lombok. Penelitian ini menggunakan metode pendekatan kualitatif dengan memperhatikan teori lempeng bumi dan pergerakanpergerakan lempeng bumi yang sudah dijelaskan sebelumnya. Hasil dari penelitian ini menunjukkan adanya keterkaitan antara pergeseran lempeng bumi dengan frekuensi terjadinya gempa bumi di Pulau Lombok. Lempeng tektonik aktif dunia yang dimana pergerakan dua diantaranya (Lempeng IndoAustralia dan Lempeng Eurasia) sangat mempengaruhi frekuensi gempa bumi dikarenakan melewati Pulau Lombok. Selain dua lempeng tektonik aktif dunia, ada pula satu Patahan yaitu Patahan Naik Flores yang terbentang dari Flores hingga Pulau Lombok yang membentuk palung dan bersifat sangat aktif,
\end{abstract}

(C) 2019 Universitas Islam Negeri Mataram

\footnotetext{
* Corresponding Author: jurnalkonstan@uinmataram.ac.id
}

Alamat korespodensi:

Gedung Pasca Sarjana Lantai 3 Kampus 2 UIN Mataram, Jl. Gajah Mada 100 Jempong Mataram, Indonesia

Email: jurnalkonstan@uinmataram.ac.id 


\section{PENDAHULUAN}

Indonesia merupakan Negara kepulauan yang terletak pada pertemuan tiga lempeng tektonik aktif dunia yaitu Lempeng Eurasia, Lempeng Indo-Australia dan Lempeng Pasifik yang tetap bergerak satu sama lainnya. Kondisi ini menjadikan Indonesia sebagai daerah tektonik aktif dengan tingkat seismisitas atau kegempaan yang tinggi. Lokasi tekonik aktif di Indonesia secara sepintas sudah dapat dipastkan berada di perbatasan lempeng tektonik. Namun efeknya bisa dirasakan pada jarak tertentu tergantung pada peluruhan energi dan geologi setempat [1]. Ada 28 wilayah di kepulauan Negara Indonesia yang dinyatakan sebagai wilayah rawan bencana gempa bumi tektonik, gunung berapi dan tsunami. Diantaranya ialah NAD, Sumatera Utara, Sumatera Barat, Bengkulu, Lampung, Banten, Jawa Tengah, DIY bagian selatan, Jawa Timur bagian selatan, Bali, NTB dan NTT [2-3].

Beberapa ratus kilometer di sebelah selatan Lombok terdapat salah satu zona pertemuan lempeng tektonik besar bumi, yang menjadi sumber utama gempabumi berpotensi tsunami, menghadap bagian selatan dari pulau ini. Lombok juga rentan terhadap tsunami dari Patahan busur belakang (back arc), yang menghadap bagian utara Pulau Lombok. Jenis patahan yang terbentuk pada back arc disebut sesar naik dan memiliki potensi tinggi untuk menghasilkan gempabumi dan tsunami di daerah pesisir Lombok. Tsunami yang lebih besar di sekitar pulau mungkin akan berdampak besar pada sepanjang garis pantai yang berpenduduk padat. Oleh karena itu ahli geologi dan para ilmuwan tsunami menganggap Lombok sebagai salah satu daerah berisiko tinggi untuk bahaya tsunami di Indonesia [4].

Oleh karena demikian kuatnya tendensi perubahan skema kegempaan di Indonesia selang satu dekade terakhir, yang ditandai dengan berpindahnya epicenter di laut dari kawasaan Barat menuju Timur Indonesia yang pastinya akan melewati bagian Tengah Indonesia, permasalahan yang muncul sekarang adalah bagaimana pola subduksi lempeng tektonik di Pulau Lombok. Mengingat begitu pentingnya pola penunjaman lempeng diketahui untuk mendapatkan solusi dari permasalah tersebut [5]. Lombok pernah mengalami gempa bumi besar dan tsunami di masa lalu. Dikarenakan lokasinya yang dekat dengan zona subduksi dan sejarah gempa buminya, komunitas sains menganggap bahwa Lombok juga akan terdampak oleh tsunami di masa depan - meskipun prediksi yang tepat tidak mungkin dibuat. Maka penelitan dimulai dengan menganalisis pergeseran lempeng bumi yang meningkatkan potensi terjadinya gempa bumi di Pulau Lombok [6-7].

\section{METODE PENELITIAN}

Penelitian ini menggunakan pendekatan studi kasus karena peneliti hanya mengumpulkan data yang sudah tersedia serta memahami dan mendalami kembali data yang sudah ada sehingga mendapatkan kesimpulan yang menjadi tujuan penelitian. Kehadiran peneliti sebagai pihak pengumpul data sehingga peneliti harus selalu ada dilokasi pengambilan data saat akan mengambil data yang dibutuhkan oleh peneliti itu sendiri. Teknik analisis data yang peneliti gunakan adalah reduksi data, display data dan penarikan kesimpulan. Untuk mengecek keabsahan data, peneliti kembali melakukan beberapa pendalaman teori serta 
observasi kembali untuk memastikan data yang diteliti tidak salah. Secara umum sistematika penelitian yang dilakukan digambarkan dalam Gambar 1 .

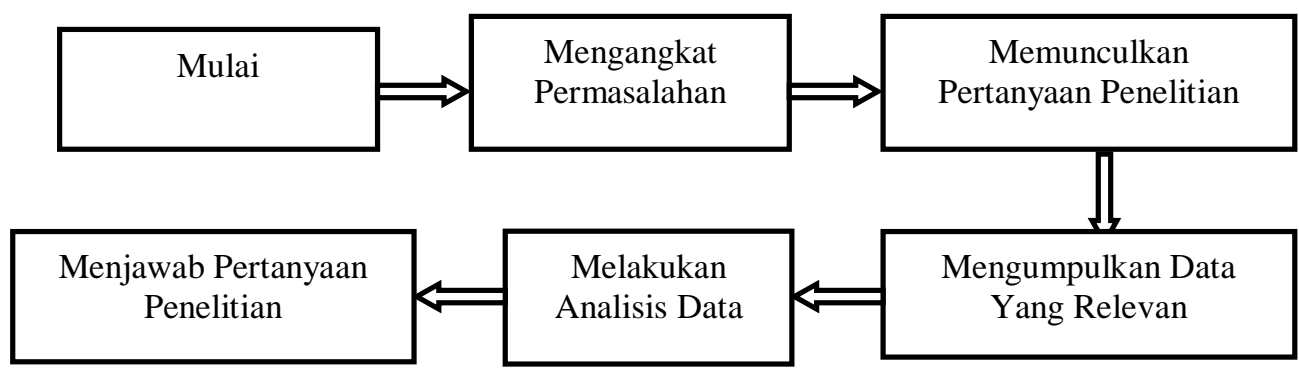

Gambar 1. Sistematika Penelitian

Lokasi penelitian atau pengambilan data dalam penelitian ini adalah BMKG Provinsi NTB Stasiun Geofisika Mataram yang bertempat di Ampenan. Alasan peneliti memilih lokasi tersebut adalah untuk memiliki data yang relevan dengan penelitian yang akan dilakukan. Dalam proses pengambilan data, peneliti diberikan data gempa yang terjadi di Provinsi NTB dari tahun 2014-2018. Di karenakan batasan wilayah penelitian yang dilakukan peneliti hanya mencakup Pulau Lombok saja, maka dilakukan reduksi data. Dimana data gempa di Provinsi NTB peneliti petakan berdsarkan batas wilayah Bujur dan Lintang sehingga akan menghasilkan data gempa di Pulau Lombok saja.

\section{HASIL DAN PEMBAHASAN}

Pulau Lombok adalah sebuah pulau di kepulauan Sunda Kecil atau Nusa Tenggara yang terpisah oleh Selat Lombok dari Pulau Bali disebelah barat dan Selat Alas dari Pulau Sumbawa di sebelah timur yang menjadi bagian wilayah dari Provinsi Nusa Tenggara Barat (NTB) seperti pada gambar 2. Wilayah Provinsi Nusa Tenggara Barat (NTB) meliputi 2 pulau besar yaitu Lombok dan Sumbawa. Secara geografis Pulau Lombok terletak di titik koordinat $8^{\circ} 565^{\prime}$ LS dan $116^{\circ} 351^{\prime}$ BT dengan total luas wilayah $4.514,11 \mathrm{~km}^{2}$. Topografi pulau ini didominasi oleh gunung berapi yaitu Gunung Rinjani yang ketinggiannya mencapai $3.726 \mathrm{~m}$ di atas permukaan laut dan menjadikannya yang ketiga tertinggi di Indonesia.

Pergerakan lempeng tidak secara langsung dipengaruhi oleh rotasi bumi pada sumbunya. Seperti yang kita ketahui bahwa kecepatan rotasi yang terjadi pada bola bumi akan semakin cepat ke arah ekuator. Pada prinsip bagian kutub (euler pole) masuk ke dalam sebuah lingkaran besar pergerakan lempeng bumi, yang dimana arah ekuator masuk ke dalam lingkaran kecil. Gerak relatif dari lempeng sesuai dengan proses pembalikan medan magnet bumi yang membuktikan adanya perubahan evolusi bumi di daerah Mid-Oceanic Ridge. Untuk menentukan jalur dari lempeng tektonik adalah dengan mengamati distribusi dari gempa-gempa dangkal yang terjadi. Sumber dari gempa bumi ada pada batas lempeng-lempeng tektonik serta sesar-sesar yang aktif.

Indonesia berada diantara 3 lempeng aktif dunia dan Pulau Lombok berada pada dua diantaranya. Dua lempeng tersebut adalah lempeng Indo-Australia dan lempeng Eurasia. Selain kedua lempeng tersebut, Pulau Lombok juga berada pada 
zona atau wilayah dari Patahan Naik Flores. Lempeng bumi tentu saja terus bergerak aktif dikarenakan aktivitas pada inti bumi yang terus menerus terjadi. Pergeseran-pergeseran aktif lempeng-lempeng tersebut tentu mempengaruhi terjadinya gempa bumi di Pulau Lombok. Lempeng Indo-Australia dan lempeng Eurasia yang terus bergerak akan bertumbukkan pada suatu titik yang kemudian disebut dengan zona subduksi. Yang dimana zona ini juga terdapat di wilayah Pulau Lombok. Namun gempa yang di akibatkan pada zona subduksi biasanya gempa berkekuatan kecil namun sewaktu-waktu bisa berkekuatan besar akibat pelepasan energi yang tersimpan pada zona subduksi tersebut.

Pada lempeng atau Patahan Naik Flores hal yang sama pun terjadi. Aktivitas aktif inti bumi sangat mempengaruhi pergerakannya. Namun pada Patahan Naik Flores gempa yang terjadi cenderung berkekuatan besar dikarenakan Patahan Naik Flores bersifat dangkal. Pergeseran yang terjadi pada lempeng bumi setiap tahunnya bisa mencapai angka $7-9 \mathrm{~km}$. Hal tersebut tergantung kepada aktifitas inti bumi, karena lempeng bergeser dikarenakan panas inti bumi yang membuat selubung bumi bergerak. Selubung bumi yang bergerak inilah yang menyebabkan lempeng bumi mengalami pergeseran. Seperti yang sudah dibahas sebelumnya, gempa bumi merupakan kejadian dimana berguncangnya bumi yang diakibatkan oleh tumbukan antar lempeng bumi, patahan aktif aktifitas gunung api, runtuhan batuan. Namun dibandingkan dengan aktifitas dari gunung api maupun runtuhan batu, tumbukan antar lempeng bumi masih menjadi alasan mayoritas dari terjadinya gempa bumi.

Frekuensi terjadinya gempa bumi di Pulau Lombok kian tahun kian meningkat, sesuai dengan data yang telah ditunjukkan sebelumnya. Hal ini memang dikarenakan Pulau Lombok sendiri memang rawan gempa. Jika diperhatikan kembali, di utara Flores hingga Lombok terdapat patahan atau sesar yang memanjang sejak dari Flores hingga ke Lombok. Patahan tersebut sebagai respons terhadap desakan Kontinen Australia. Patahan yang disebut Flores Thrust (Patahan Naik Flores) ini berada di bawah laut. Kenampakannya dari rekaman seismik refleksi atau bisa sebut sebagai alat untuk melihat anatomi kerak bumi sangat jelas yaitu dari ujung timur Laut Flores, tampak dasar laut terpatahkan, dimana bagian utara menyusup ke bawah. Patahan itu dapat diikuti dengan jelas hingga Lombok. Di utara Bali, deformasi melemah atau tidak sekuat di bagian Lombok. Jika diamati dari peta aktivitas kegempaan atau seismisitas Pulau Lombok, nampak seluruh Pulau Lombok dikelilingi sebaran titik episenter. Meskipun kedalaman hiposenternya dan magnitudonya bervariasi, namun jelas wilayah Lombok_memang aktif gempa yang bersumber dari subduksi lempeng, Sesar Naik Flores, dan sesar lokal di Pulau Lombok dan sekitarnya.

Melihat dari hal tersebut, maka tak heran jika jumla gempa bumi terus meningkat setiap tahunnya. Data yang didapatkan oleh peneliti menunjukkan peningkatan yang lumayan tinggi pada tahun 2018. Hal ini dikarenakan lempeng disekitar Pulau Lombok yang terus bergerak dan membentuk sesar atau patahanpatahan baru yang kemudian pada satu titik akan bertemu dan mengakibatkan gempa. Pergeseran lempeng atau patahan ini ditinjau dari jenisnya masuk kedalam kategori konvergensi. Hal ini dikarenakan ditinjau dari posisi atau letak patahan yang berada dari NTT hingga ke NTB yang akan melewati palung laut yang dihasilkan oleh penyusupan lempeng samudera India-Australia dan lempeng benua 
Eurasia (Sumatera). Sedangkan jika ditinjau dari tepi lempengnya, Pulau Lombok termasuk dalam jenis tepi destruktif. Akibat pergerseran lempeng tersebut gempa dengan skala magnitudo kecil maupun besar bisa terjadi. Pada bab sebelumnya telah dijelaskan ada beberapa kelompok gempa berdasarkan magnitudonya yaitu gempa lemah, gempa sedang, gempa kuat dan gempa sangat kuat. Pada Gambar 3. menunjukkan grafik gempa dengan skala magnitudo tertinggi pada setiap kabupaten di Pulau Lombok dari tahun 2014-2018 berdasarkan data yang peneliti dapatkan.

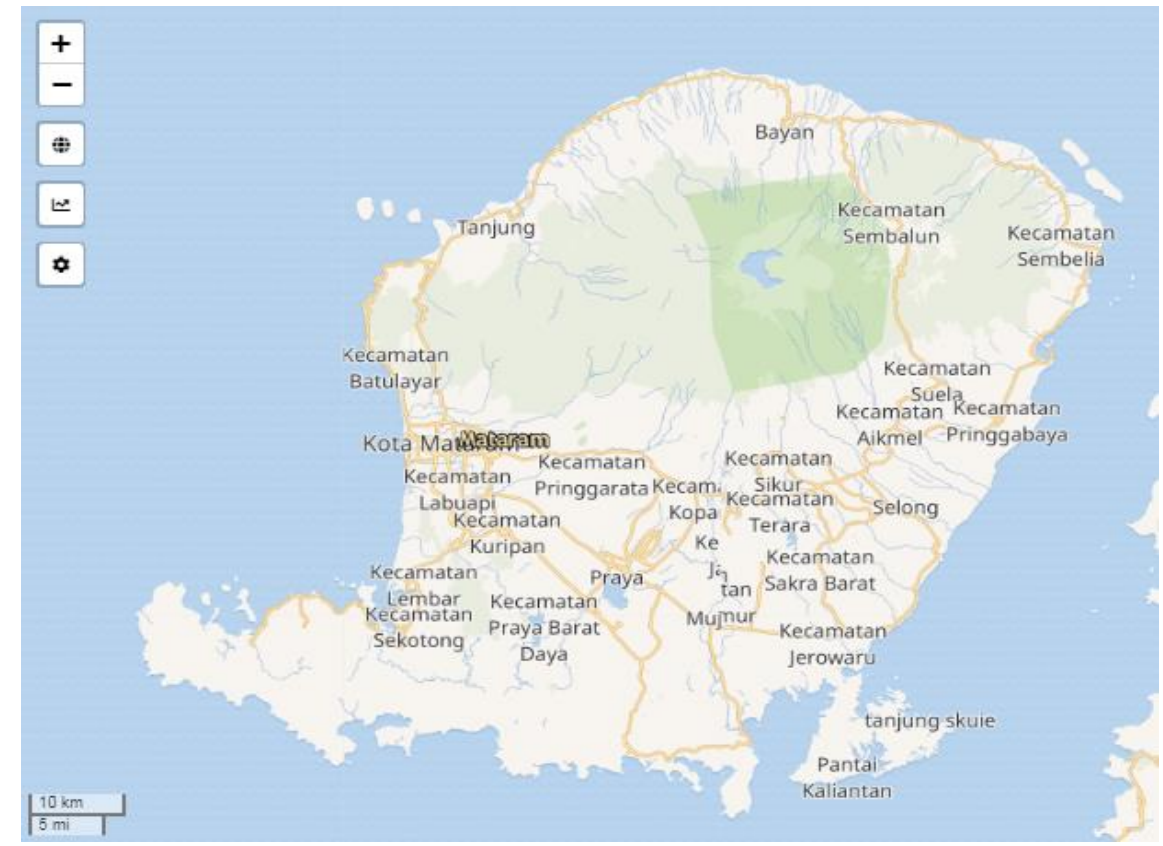

Gambar 2. Peta Pulau Lombok

\section{Grafik Max Kekuatan Gempa Pertahun di Setiap Kabupaten}

Mataram $\quad$ Kab. Loteng Kab. Lobar $\square$ KLU $\square$ Kab. Lotim

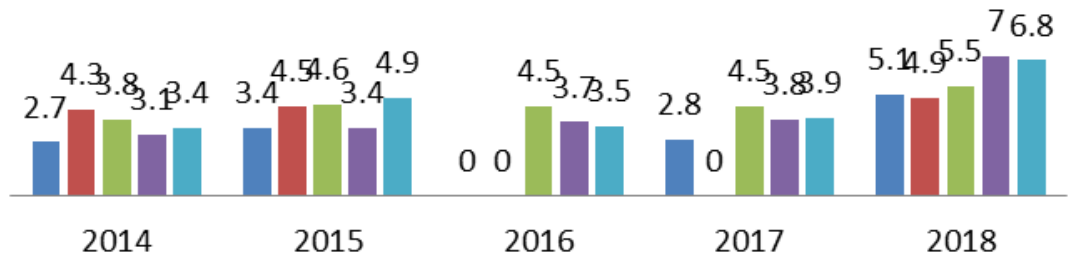

Gambar 3. Grafik Max kekuatan gempa pertahun di setiap kabupaten di Pulau Lombok 
Jika dilihat dari grafik tersebut dapat ditarik kesimpulan bahwa kekuatan gempa setiap tahunnya terus berubah. Gempa terbesar terjadi pada tahun 2018 diwilayah KLU dengan kekuatan sebesar 7 SR yang disebabkan oleh Patahan Naik Flores yang kemudian disusul oleh Kabupaten Lombok Timur dengan kekuatan 6.8 SR. Pada wilayah Kabupaten Lombok Timur selain adanya pergerakan lempeng tektonik, gempa juga banyak terjadi akibat aktivitas vulkanik gunung Rinjani. Namun gempa ini tidak mempunyai kekuatan besar hingga tidak dapat dirasakan oleh masayarat sekitar. Gempa-gempa yang dapat dirasakan oleh masayarat adalah gempa dengan kekuatan diatas 4 SR. Gempa dengan kekuaan tersebut bisa tidak terjadi pada suatu daerah tertentu dikarenakan adanya pengaruh dari lempeng yang ada disekitar Pulau Lombok.

Seperti yang dapat dilihat pada tahun 2016 pada Kota Mataram dan Kabupaten Lombok Tengah yang tidak terjadi gempa dengan kekuatan diatas 4 SR namun tetap mendapatkan gempa dengan kekuatan kurang dari 4 SR. Pada tahun 2017 pun Kabupaten Lombok tengah tidak terjadi gempa dengan kekuatan diatas 4 SR. Ini bisa terjadi dikarenakan beberapa faktor. Akan tetapi faktor yang paling mendominasi adalah faktor dari titik koordinat lokasi pada wilayah Lombok Tengah. Daerah Lombok Tengah menurut BPBD Provinsi NTB merupakan salah satu wilayah dengan kontur dan sifat tanah yang paling stabil di Pulau Lombok.

Hal ini juga mengakibatkan gempa-gempa kecil yang terjadi di wilayah Lombok Tengah tidak pernah dirasakan oleh masyarat. Akan tetapi pada tahun 2018, wilayah Lombok Tengah juga sering merasakan gempa-gempa besar walaupun wilayahnya bukan merupakan titik episenter dari gempa besar tersebut. Jika diperhatikan kembali gempa-gempa yang terjadi di Pulau Lombok setiap tahunnya terus bertambah dan mengalami peningkatan pesat pada tahun 2018 seperti yang ditunjukkan Gambar 4 berikut;

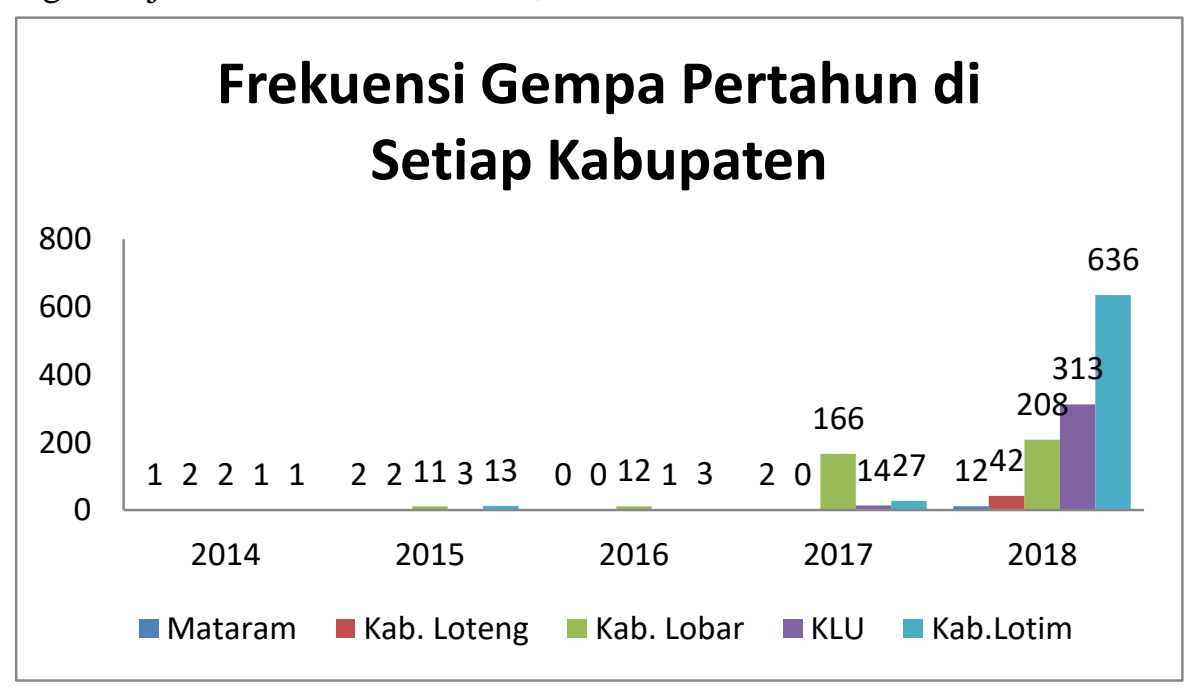

Gambar 4. Grafik frekuensi gempa pertahun di setiap kabupaten di Pulau Lombok 
Data menunjukkan pada tahun 2014, frekuensi gempa yang terjadi di Pulau Lombok hanya berkisar diangka kecil yaitu 7 kali dalam setahun dengan penyebaran 1 gempa di wilayah Mataram, Lombok Timur dan KLU, 2 gempa di wilayah Lombok Barat dan Lombok Tengah. Pada tahun 2015 meningkat menjadi 31 kali dengan penyebaran 2 gempa di wilayah Mataram dan Lombok Tengah, 11 gempa di wilayah Lombok Barat, 3 gemap di wilayah KLU dan 13 gemap di wilayah Lombok Timur. Lalu mengalami penurunan frekuensi pada tahun 2016 hingga hanya menjadi 16 kali dalam setahunnya dengan penyebaran 12 gempa di wilayah Lombok Barat, 1 gempa di wilayah KLU dan 3 gempa di wilayah Lombok Timur. Pada wilayah Mataram dan Lombok Tengah tidak terjadi satupun gempa sepanjang tahun 2016.

Kemudian meningkat tajam pada tahun 2017 hingga menyentuh angka 209 kali dalam setahun dengan penyebaran 2 gempa di wilayah Mataram, 166 gempa di wilayah Lombok Barat, 14 di wilayah KLU dan 27 gempa di wilayah Lombok Timur. Pada wilayah Lombok Tengah, ditahun 2017 pun tak terdeteksi telah terjadi gempa sepanjang tahunnya. Dan data yang terakhir adalah pada tahun 2018 menunjukkan peningkatan paling tinggi yaitu 1.211 kali dengan penyebaran 12 gempa di wilayah Mataram, 42 gempa di wilayah Lombok Tengah, 208 gempa di wilayah Lombok Barat, 313 gempa di wilayah KLU dan 636 gempa di wilayah Lombok Timur. Gempa pada tahun 2018 merupakan gempa dengan frekuens terbanyak dan terjadi dalam waktu yang berdekatan. Para ahli meyatakan penyebab utama gempa ini adalah Patahan Naik Flores yang memang membentang dari timur laut Flores sampai ke Pulau Lombok.

Jika mengkaitkan frekuensi gempa bumi di Pulau Lombok dengan bagaimana pergeseran lempeng mampu meningkatkan potensi gempa bumi di Pulau Lombok jelas ada suatu hubungan yang tidak bisa diabaikan. Dari pemaparan diatas dapat dengan jelas disimpulkan bahwa pergerakan lempeng atau patahan yang ada disekitar Pulau Lombok terutama Patahan Naik Flores mampu meningkatkan potensi terjadinya gempa bumi di Pulau Lombok.

\section{SIMPULAN DAN SARAN}

Pergeseran lempeng bumi di Pulau Lombok disebabkan oleh penyusupan lempeng samudera Indo-Australia dan lempeng benua Eurasia (Sumatera) yang ditinjau dari patahan yang membetuk palung dan membentang dari Flores hingga ke Pulau Lombok. Lempeng yang ada disekitar Pulau Lombok terus bergerak sesuai dengan aktivitas yang terjadi pada bumi, baik pada inti bumi maupun lapisan litosfer. Jadi, tidak ada kemungkinan lempeng akan berhenti bergeser sehingga gempa bumi berhenti terjadi.

Pergeseran lempeng bumi yang ada di sekitar Pulau Lombok tentu mempengaruhi frekuensi terjadinya gempa bumi di Pulau Lombok, seperti datadata yang telah di paparkan, peningkatan tajam frekuensi gempa bumi di Pulau Lombok pada tahun 2018 terutama pada bulan Juli hingga September dikarenakan bergeraknya Patahan Naik Flores. Selain itu, letak Pulau Lombok yang dikelilingi sesar-sesar serta titik rawan bencana gempa bumi juga menjadi penyebab utama meningkatnya gempa bumi di Pulau Lombok. Sesar tersebut berasal dari patahanpatahan lempeng yang terus bergerak hingga bertumbukan dan membentuk 
subduksi yang kemudia membentuk energy atau stress yang kemudian dilepaskan dalam bentuk gempa bumi.

\section{DAFTAR PUSTAKA}

[1] A, Wirma Sari,dkk. "Analisis Rekahan Gempa Bumi dan Gempa Bumi Susulan Dengan Menggunakan Metode Omori”. Jurnal Sains dan Pendidikan Fisika. Jilid 8, Nomor 3, Desember 2012

[2] Achmad Yasir Baeda,dkk."Kajian Potensi Tsunami Akibat Gempa Bumi Bawah Laut di Perairan Pulau Sulawesi”. Vol. 19 No. 1 April 2012 ISSN 0853-2982

[3] Akmam. "Subduksi Lempeng Indo-Australia Pada Lempeng Eurasia di Pantai Barat Sumatera Barat". Jurnal Sainstek Vol. Iii No.1 ISSN: 20858019

[4] Arief Mustofa Nur . "Gempa Bumi, Tsunami dan Mitigasinya". Volume 7 No. 1 Januari 2010

[5] Dewi Reny Anggraeni.dkk, "Peta-Peta Bahaya Tsunami Untuk Lombok, Dokumentasi Teknis (Versi Indonesia)", GIS IZ dan DLR, 2013

[6] Niko Irjaya Desmonda,dkk. "Penentuan Zona Kerentanan Bencana Gempa Bumi Tektonik di Kabupaten Malang Wilayah Selatan". Jurnal Teknik Pomits Vol. 3, No. 2, (2014) ISSN: 2337-3539

[7] Sunarjo,dkk, "Gempa Bumi Edisi Populer”, BMKG, Jakarta, 2012 